\title{
Role of innate lymphoid cells in obesity and metabolic disease (Review)
}

\author{
JIRAKRIT SAETANG $^{1^{*}}$ and SURASAK SANGKHATHAT ${ }^{2 *}$ \\ ${ }^{1}$ Department of Biomedical Sciences; ${ }^{2}$ Tumor Biology Research Unit, Department of Surgery, \\ Faculty of Medicine, Prince of Songkla University, Songkhla 90110, Thailand
}

Received February 27, 2017; Accepted August 14, 2017

DOI: $10.3892 / \mathrm{mmr} .2017 .8038$

\begin{abstract}
The immune system has previously been demonstrated to be associated with the pathophysiological development of metabolic abnormalities. However, the mechanisms linking immunity to metabolic disease remain to be fully elucidated. It has previously been suggested that innate lymphoid cells (ILCs) may be involved in the progression of numerous types of metabolic diseases as these cells act as suppressors and promoters for obesity and associated conditions, and are particularly involved in adipose tissue inflammation, which is a major feature of metabolic imbalance. Group 2 ILCs (ILC2s) have been revealed as anti-obese immune regulators by secreting anti-inflammatory cytokines and promoting the polarization of M2 macrophages, whereas group 1 ILCs (ILC1s), including natural killer cells, may promote adipose tissue inflammation via production of interferon- $\gamma$, which in turn polarizes macrophages toward the M1 type. The majority of studies to date have demonstrated the pathological association between ILCs and obesity in the context of adipose tissue inflammation, whereas the roles of ILCs in other organs which participate in obesity development have not been fully characterized. Therefore, identifying the roles of all types of ILCs as central components mediating obesity-associated inflammation, is of primary concern, and may lead to the discovery of novel preventative and therapeutic interventions.
\end{abstract}

\section{Contents}

1. Introduction

Correspondence to: Dr Surasak Sangkhathat, Tumor Biology Research Unit, Department of Surgery, Faculty of Medicine, Prince of Songkla University, Kanjanawanit Road, Hat Yai, Songkhla 90110, Thailand

E-mail: surasak.sa@psu.ac.th

*Contributed equally

Key words: innate lymphoid cells, obesity, metabolic disease, inflammation, immune system
2. Interplay between diets, inflammation and gut microbiota in obesity

3. Innate lymphoid cells (ILCs)

4. Relationship between ILCs and obesity

5. Determining whether intestinal ILCs influence the deve lopment of obesity

6. Conclusion

\section{Introduction}

Obesity, as defined by an excess of adipose tissue, has increased globally in most of the westernized world over recent decades. This condition is associated with several chronic complications, such as hypertension, coronary heart disease, hyperglycemia, hypertriglyceridemia, dyslipidemia and insulin resistance (1). Although over 30 gene loci combinations have been identified as being associated with the development of obesity and metabolic disease (2), these loci are responsible for only 2-3\% of the incidence of these conditions. Other causes of obesity are known to include energy-dense diets high in saturated fat and sugar, and the sedentary lifestyles common in the modern world (3-5). In recent years, animal models have been developed to study such things as diet-induced obesity to study the underlying mechanisms of obesity and related diseases.

It is further generally accepted that obesity and metabolic disorders are associated with chronic, low-grade systemic inflammation (6). This kind of inflammation originates predominantly in adipose tissue, which leads to greater numbers of immune cells, resulting in the activation of other cells, such as adipocytes, which cause adipose tissue remodeling and further incitement of the inflammatory process (7). Interestingly, malnutrition, including excessive energy intake, increase fat accumulation, and lipotoxicity, can activate the expression of pro-inflammatory effector molecules in metabolic tissues and cells involved in innate immunity $(8,9)$. Although many recent studies have focused on the role of adipose tissue macrophages (ATMs), which are known to be the main factor initiating systemic inflammatory promotion in obesity, the recently identified innate lymphoid cells (ILCs) have also been reported to play a role in the inflammatory process in obese adipose tissue (10).

In this article, we review the current understanding of the complex interplay between the types of ILCs that have been 
found to link inflammation to obesity. We also discuss the cellular and molecular basis of obesity-induced inflammation and the functional role of each type of ILC. Finally, we open a new discussion by noting that even if adipose tissue is accepted as a major cause of systemic inflammation, it is still unclear whether any metabolic-related organs can influence obesity-related pathologies.

\section{Interplay between diets, inflammation and gut microbiota in obesity}

In the last decade, various mechanisms linking immunity, metabolic abnormalities, and intestinal microbiota have been proposed (11). Although the cause of metabolic inflammation in obesity has not been fully clarified, some studies have shown that diet-induced dysbiosis may be the origin of this inflammation $(9,12)$, and this scenario is related to increased intestinal permeability caused by changes of normal flora and their metabolites $(13,14)$. The studies found that diet can be associated with structural variations in gut microbiota, especially the 'Western' diet, which has various effects on host gastrointestinal tract (GI) metabolism, microbiota and immune homeostasis $(15,16)$.

Changes in microbiota can affect gut metabolic activity in various way, such as increasing the production of short-chain fatty acids (SCFAs), which leads to alterations of intestinal homeostasis. Decreased bacterial diversity and alteration of representative bacterial genes and metabolic pathways can be found in obese individuals (17). In particular, high-fat diets or diets low in fiber have been associated with a higher abundance of Firmicutes (18), while studies comparing obese individuals and their lean twins have also shown a higher predominance of Firmicutes and lower abundance of Bacteroidetes $(17,19)$ in the obese subjects. It must be noted, however, that other studies have not found similar differences $(20,21)$.

Further investigations have been shown that the complex interplay between diet and the intestinal microbiota in the context of obesity can lead to the release of gut-derived inflammatory factors into the circulation, resulting in the development of obesity (22). Lipopolysaccharide (LPS), a potent inflammatory mediator of Gram-negative bacteria, has been recently shown to trigger inflammation in obese and metabolic syndrome individuals by signaling through the CD14/TLR4 pathway (23). Such LPS-induced systemic inflammation may result from intestinal permeability mediated by a high-fat diet since increases in the translocation of intestinal Gram-negative bacteria (which produce LPS) to the mesenteric lymph nodes (mLNs) and mesenteric fat can be found in high-fat diet-fed mice (24). One recent study found that antibiotic treatment or CD14 suppression appeared to reduce inflammatory cytokine expression and improve weight gain in high-fat diet mice, indicating a role of the microbiota in the inflammatory process (25). Therefore, it is possible that intestinal inflammation may lead to GI permeability, resulting in an increase in circulating LPS and bacterial DNA, which promote systemic inflammation and insulin resistance in both mice and humans (26).

This metabolic inflammation, which does not necessarily involve pathogens, is associated with inflammatory adipose tissue and higher immune cell accumulation in fatty tissue regions (Fig. 1) (6). ATMs appear to play a major function in the regulation of obesity-induced inflammation, and different types of macrophage can cause the different effects in adipose tissue. Currently, macrophages are divided into 2 groups, the M1 and M2 types. M1 macrophages characterized by the expression of

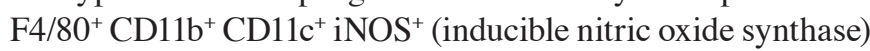
and the production of pro-inflammatory cytokines [IL-1 $\beta$, IL-6, IL-12, tumor necrosis factor (TNF)- $\alpha$, MCP-1] is considered to be involved in adipose tissue inflammation, while the M2 type macrophages, which express $\mathrm{F} 4 / 80^{+} \mathrm{CD} 1 \mathrm{c}^{-} \mathrm{CD} 301^{+}$ $\mathrm{Arg} 1^{+} \mathrm{CD} 206^{+}$and produce anti-inflammatory cytokines [IL-1 receptor antagonist, IL-4, IL-10, transforming growth factor (TGF)- $\beta 1$ ], have been known to suppress inflammation in adipose tissue $(27,28)$. Other studies have also suggested that high levels of inflammatory cytokines in adipose tissue during obesity are consistent with increasing macrophage numbers, which can be described as a metabolic activation instead of the classical activation related to infections $(29,30)$. In addition to macrophages, lymphocytes are strongly associated with inflammatory processes in obesity. Although there are several types of lymphocytes that are related to obesity and metabolic syndrome, pro-inflammatory Th1, Th17 and $\mathrm{CD}^{+} \mathrm{T}$ cells predominate over anti-inflammatory regulatory $\mathrm{T}$ (Treg) cells and Th2 cells, which are found in higher proportions in lean adipose tissue $(7,31)$. One study found that mice fed a high-fat diet displayed more Th1 polarization and IFN- $\gamma$ production, which occurred several months after macrophage accumulation and insulin resistance (32), while the number of Treg cells was decreased in the adipose tissue of obese mice; insulin sensitivity was also improved when these cells were increased (Fig. 1) (31).

\section{Innate lymphoid cells (ILCs)}

ILCs are a recently discover type of innate immune cells, which have been identified as an important player in lymphoid organogenesis, tissue defense, epithelial tissue homeostasis and the amplification of immune responses $(33,34)$. Although it has been agreed that ILCs participate in the defense against pathogens (35), some studies have suggested they could also be involved in some systemic conditions, such as chronic inflammation and autoimmune disorders (36,37). ILCs have been defined as lymphoid-derived, immune lineage negative ( Lin $\left.^{-}\right)$, Th cytokine expressing cells (33). Currently, three distinct groups of ILCs which exhibit a functional diversity mirroring three types of effector $\mathrm{CD}^{+}{ }^{+} \mathrm{T}$-cells have been identified: Group 1 ILCs, equivalent to Th1 T cells, group 2 ILCs to Th2 cells, and group 3 ILCs to Th17 and Th22 cells (Fig. 2) (35).

Group 1 ILCs. Group 1 ILCs are characterized based on their ability to produce IFN- $\gamma$, and have been sub-grouped into two main types, conventional NK (cNK) cells and ILC1 cells (38). cNK cells have cytotoxic ability and can be found in numerous organs as they recirculate between the blood and tissues while ILC1s have only limited cytotoxicity, but have the ability to produce several types of inflammatory cytokines mirroring Th1 cells $(39,40)$. Both types of group 1 ILCs can produce TNF and IFN- $\gamma$ as a uniquely inflammatory profile when these cells are stimulated with IL-12, IL-15, or IL-18, and rely on T-bet transcription factor (T-bet) as a key transcription factor $(41,42)$. 


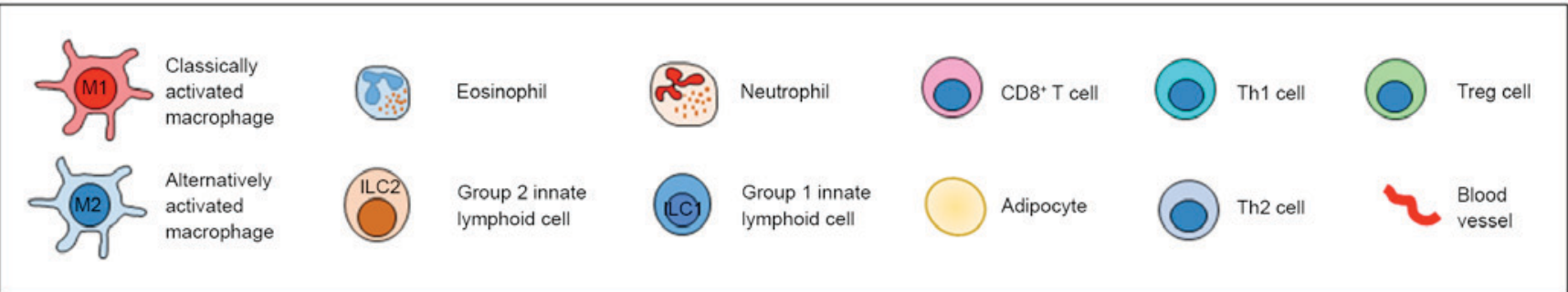

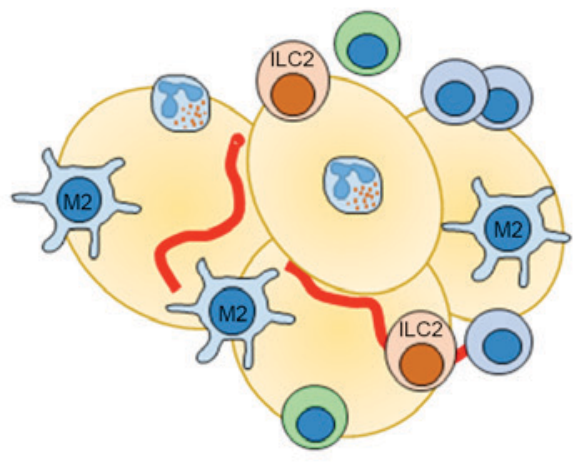

Lean adipose tissue

- Anti-inflammatory environment

- Adipocyte hyperplasia

- Insulin sensitive

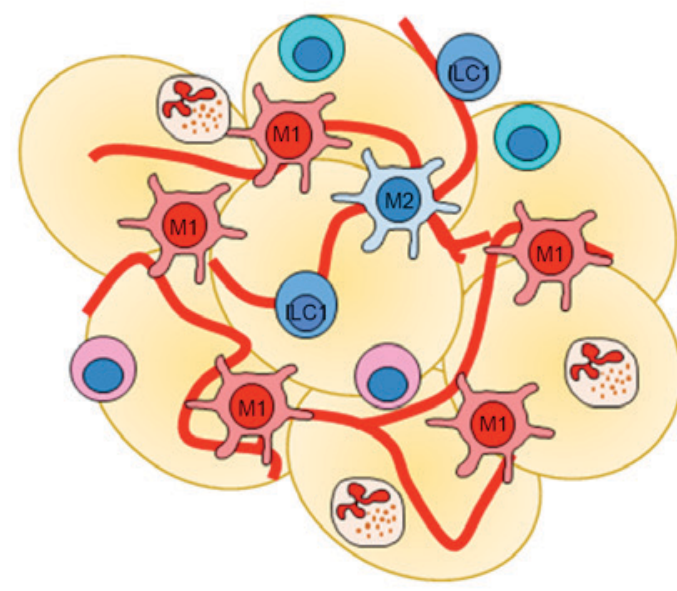

Obese adipose tissue

- Pro-inflammatory environment

- Adipocyte hypertrophy

- Cellular stress

- Hypoxia and fibrosis

Insulin resistance

Figure 1. The different environment between lean and obese adipose tissues. The most common immune cells found in lean adipose tissue are M2 macrophages, which create the anti-inflammatory environment in cooperation with ILC2s, eosinophils, Treg and Th2 cells. On the other hand, obese adipose tissue is dominated by M1 macrophages, neutrophils, ILC1, Th1 as well as CD8 ${ }^{+} \mathrm{T}$ cells, which all promote an inflammatory condition, which in turn support insulin resistance. Treg, regulatory T cells; ILC, innate lymphoid cell.
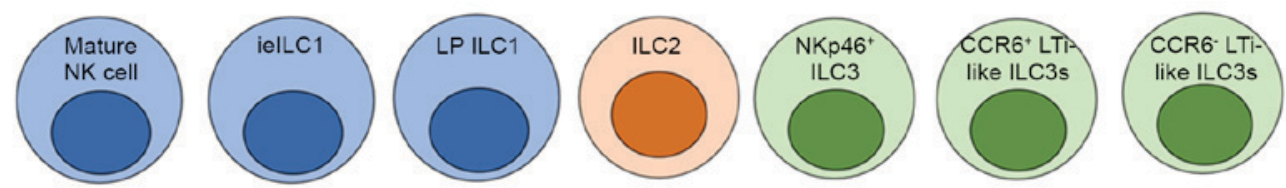

\begin{tabular}{|c|c|c|c|c|c|c|c|}
\hline $\begin{array}{c}\text { Transcription } \\
\text { factors }\end{array}$ & $\begin{array}{l}\text { T-bet', } \\
\text { Eomes }{ }^{+}\end{array}$ & T-bet', Eomes ${ }^{+}$ & $\begin{array}{l}\text { T-bet*, } \\
\text { Eomes }\end{array}$ & $\begin{array}{l}\text { GATA3* } \\
\text { ROR } \alpha^{+}\end{array}$ & \multicolumn{3}{|c|}{ RORyt* } \\
\hline $\begin{array}{l}\text { Surface } \\
\text { markers }\end{array}$ & $\begin{array}{c}\mathrm{Lin}^{*} \mathrm{NK} 1.1^{+} \\
\mathrm{NKp} 46^{+} \\
\mathrm{DX} 5^{+} \\
\text {CD49a' } \\
\text { CD69. }\end{array}$ & $\begin{array}{c}\text { Lin } \mathrm{NK}^{-1^{+}} \\
\mathrm{NKp} 46^{+} \mathrm{D} \times 5^{-} \\
\mathrm{CD} 49 \mathrm{a}^{+} \\
\mathrm{CD} 69^{+}\end{array}$ & 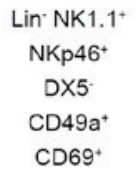 & $\begin{array}{c}\text { Lin ICOS+ } \\
\text { T1/ST2 } 2^{+} \text {Thy1. } \\
2^{+}\end{array}$ & $\begin{array}{c}\text { Lin }^{-} \\
\text {Thy } 1^{+} \mathrm{CD} 127 \\
{ }^{+} \mathrm{NKp} 46^{+}\end{array}$ & $\begin{array}{l}\text { Lin-Thy 1+ } \\
\text { CD127+ } \\
\text { NKp46- } \\
\text { CCR6 }^{+}\end{array}$ & $\begin{array}{l}\text { Lin- Thy } 1^{+} \\
\text {CD127+NK } \\
\text { p46-CCR6 }\end{array}$ \\
\hline Cytokines & \multicolumn{3}{|c|}{$\mathrm{IFN}-\gamma$} & IL-5, IL-13 & \multicolumn{3}{|c|}{ IL-22 } \\
\hline $\begin{array}{l}\text { Disease } \\
\text { association }\end{array}$ & \multicolumn{3}{|c|}{ Inflammatory condition and IBD } & $\begin{array}{c}\text { Allergy and } \\
\text { ashma }\end{array}$ & \multicolumn{3}{|c|}{ IBD } \\
\hline
\end{tabular}

Figure 2. The important transcription factors and cell surface markers for each type of innate lymphoid cells. ${ }^{*} \mathrm{Lin}=\mathrm{TCR} \beta^{+} \mathrm{CD} 3 \varepsilon^{+} \mathrm{CD} 19^{+} \mathrm{TCR} \gamma \delta^{+} \mathrm{Ly} 6 \mathrm{G}^{+}$ F4/80+ cells. ILC, innate lymphoid cell; ieILC1, intraepithelial ILC1; LP ILC1, lamina propria-resident ILC11; ILC1, group 1 ILC; ILC2, group 2 ILC; ROR $\alpha$, retinoic acid-related orphan receptor $\alpha$; ROR $\gamma \mathrm{t}$, retinoic acid receptor-related orphan receptor $\gamma \mathrm{t}$; IBD, inflammatory bowel disease.

Generally, mice resting mature cNK cells have been identified as $\mathrm{Lin}^{-} \mathrm{CD} 3 \varepsilon^{+} \mathrm{NK} 1.1^{+} \mathrm{NKp} 46^{+} \mathrm{CD} 49 \mathrm{~b}(\mathrm{DX} 5)^{+}$Eomes $^{+}$ whereas Lin $\mathrm{CD}^{-} \varepsilon^{-} \mathrm{CD} 56^{+} \mathrm{NKp} 46^{+} \mathrm{NKp} 44^{-}$has been used in humans (Fig. 2) (43). Two main groups of cNK cells have been identified, including the majority of blood cNK cells, which are CD56 $6^{\text {low }}$ and highly cytotoxic, and CD56 $6^{\text {high }}$ low cytotoxicity cNK cells, which produce a high number of inflammatory cytokines (44). 
Unconventional NK cells or, also known as ILC1s, are tissue-resident NK-like cells that are not derived from NK cell precursors and are normally found in non-lymphoid organs (45). A defining distinction between NK cells and ILC1s is the expression of the transcription factor, Eomes (39). NK cells are Eomes $^{+}$and require this transcription factor to develop while ILC1s are Eomes ${ }^{-}$and do not need Eomes for their development (39). Another noticeable characteristic that differentiates ILC1s from NK cells is their tissue resident markers, CD49a and CD69 (39). These tissue resident ILC1s have been found in a variety of non-lymphoid tissues, including the small intestine mucosa, liver, salivary glands, and female reproductive tract (45). Interestingly, recirculation of these tissue-resident ILC1s does not seem to occur, and, in mice, the existence of these ILC1s is likely maintained predominantly through local self-renewal instead of replenishment from blood-derived ILC1s or their precursors $(46,47)$.

Emerging evidence in recent years has demonstrated that ILC1s and NK cells in different organs show coincident but different phenotypes and functions. Intestinal and hepatic ILC1s share the CD49a ${ }^{+}$CD $49 b^{-}$phenotype, produce high IFN- $\gamma$ levels and are Eomes ${ }^{-}$and less cytotoxic than NK cells (48). The cytotoxicity of hepatic resident ILC1s is regularly mediated by TRAIL rather than perforin $(48,49)$, which is found in NK cell-mediated cytotoxicity, although mice and human NK cells can express TRAIL (50). Moreover, various studies have found that several types of group 1 ILCs that differ from $\mathrm{cNK}$ cells are resident in the gastrointestinal mucosa, e.g., intraepithelial ILC1s (ieILC1s), which express surface markers typical of intraepithelial T cells, such as CD49a, CD69, CD160, and in humans, the integrin CD103 that makes them distinct from cNK cells although ieILC1s also display canonical NK cell receptors and need the transcription factors T-bet and Eomes in their development, similar to cNK cells (42). Another type is lamina propria-resident ILC1s (LP ILC1s), which express NKp46 and NK1.1, which are found in both cNK cells and ieILC1s (45). However, mouse LP ILC1s express high levels of the IL-7 receptor $\alpha$ chain (CD127) and are negative for Eomes but positive for T-bet, which is not common in either $\mathrm{cNK}$ or ieILC1 cells (Fig. 2) (45,48).

The major function of group 1 ILCs is the potent expression of IFN- $\gamma$, which plays a crucial role in promoting immunity against intracellular pathogens (51). cNK cells are known for their rapid response after exposure to a variety of viral and bacterial pathogens (52). It is now suggested that ILC1s are the major source of IFN- $\gamma$ and TNF in orally Toxoplasma gondii-infected mice while cNK cells contribute to a lesser extent (48). Another study found that T-bet deficient mice were highly susceptible to $T$. gondii infection, and adoptive transfer of ILC1s to Rag2 $2^{-/-} \mathrm{Il}_{2} \mathrm{rg}^{-/-}$mice boosted anti-bacterial immunity (48). Importantly, it seems likely that some results from the previous studies regarded all NK-like phenotypes with an ability to produce IFN- $\gamma$ as cNK cells, which make the un-recognition of ILC1s as a separate lineage (45). Studies that specifically investigated the role of ILC1s, as compared to cNK cells, in host defenses to pathogens are only now being conducted; using specific markers for ILC1s, such as CD49a, CD127 and Eomes, may make it possible to more accurately study the specific roles of ILC1s compared to cNK cells (45).
Group 2 ILCs. ILC2s derive from common lymphoid progenitors like most lymphoid cells but lack the common lineage marker expression associated with $\mathrm{T}$ cells (CD3, CD4, and $\alpha \beta / \gamma \delta$ TCR), B cells (CD19 and CD20), and other leukocytes including CD11c, CD14, CD16, CD56, and FceR1 (53). Moreover, they are positive for CD90 (Thy1), CD25 (IL-2 receptor $\alpha$ ), IL-25R (IL-17RB), IL-33 receptor (IL-33R; ST2), and CD127 (IL-7 receptor $\alpha$ ) (Fig. 2) (54). Similar to Th2 cells, GATA3 acts as a key transcription factor for development and function of ILC2s (55), and transcription factors Id 2 and retinoic acid-related orphan receptor $\alpha$ (ROR) $\alpha$ have also be recently include as important regulators in their development $(54,56,57)$.

ILC2s can respond to IL-25, IL-33 $(57,58)$ and thymic stromal lymphopoietin (TSLP) (59), and produce type 2 cytokines, predominantly IL-5 and IL-13 (60). Several studies have shown that ILC2s can produce high levels of IL-5 and IL-13, which contribute to the immune response against helminth infection in the GI, lungs and skin $(61,62)$. ILC2s also produce IL-9, which one study found supported the accumulation of mast cells and mucus production (63). However, IL-9 expression by ILC2s was transient and dependent on IL-2 and intact adaptive immunity, suggesting that IL-9 could amplify ILC2 function (64). ILC2s can also activate $C D 4^{+} \mathrm{T}$ cells for the efficient induction of Th2 cell development by presenting an antigen to non-activated $\mathrm{CD}^{+} \mathrm{T}$ cells (65). Another study also showed that $\mathrm{OX} 40 / \mathrm{OX} 40 \mathrm{~L}$ interactions and the production of IL- 4 by ILC 2 s contributed to $\mathrm{CD} 4^{+} \mathrm{T}$-cell responses in vitro supporting the role of ILC2s-CD4 ${ }^{+} \mathrm{T}$ cell relation (66). Interestingly, lipid mediators, such as CysLTs and PGD2, and the TNF-like ligand 1A (TL1A), which have all been associated with Th2-driven diseases, have also been found to be activators of ILC2s $(67,68)$. Furthermore, basophilicand Th2-derived IL-4 also promote ILC2 activation (69). Cell-cell interactions through molecular signaling of ICOS (binds ICOS-L) and KLRG1 (binds cadherins) in ILC2s also promote ILC2 activation and survival (70,71). A recent report also demonstrated that ILC2 activation can be influenced by Treg cells, and activated ILC2 also conversely promote Treg cell maintenance (72).

It has been proposed that ILC2-derived Th2 cytokines contribute to several types of Th2-related diseases, such as chronic rhinosinusitis, asthma, atopic dermatitis, and gastrointestinal allergic disease, which have all been considered as resident sites of ILC2s (Fig. 2) (64). Clinical experiments with asthmatics have shown that IL-4, IL-5, and IL-13 inhibition give beneficial effects to asthma patients, reflecting the importance of Th2 cytokines, which are partly derived from ILC2s in asthma (73). Notably, ILC2s seem to play an important role in lung inflammation in responding to protease-containing allergens. One study showed that papain, an allergen used in the experiment, promoted allergic lung inflammation even in RAG-deficient mice, suggesting a role of ILC2 in lung inflammation (74). Moreover, airway hyper-reactivity mediated by ILC $2 s$ is found not only in non-infectious inflammation but also after influenza viral infections (75).

Another role of ILC2s in the metabolic pathway has also been found, based on the knowledge that this kind of ILC can regulate beige adipose tissue development and may promote the lean phenotype (76). Moreover, ILC2s can be detected 
in visceral adipose tissue (VAT) where they were thought to be responsible for eosinophil accumulation (77). Another study found that ILC2-depleted $\mathrm{Ragl}^{-/-}$mice became obese and showed impaired glucose tolerance, but these problems improved when ILC2 cells were transferred into these obese mice (78). Moreover, nutritional status also likely influences ILC2 biology, as vitamins A and D are known to skew the ILC3/ILC2 balance in the intestines (79).

Group 3 ILCs. There are currently two recognized sub-populations of ILC3s, the CCR6 ${ }^{+}$lymphoid-tissue inducer (LTi) ILC3s and the CCR6- ILC3s, of which the latter can be divided into two groups based on the expression of NKp46 in mice (80) and NKp44 in humans (81) (Fig. 2). All groups of ILC3s need the nuclear hormone retinoic acid receptor-related orphan receptor $\gamma \mathrm{t}(\mathrm{ROR} \gamma \mathrm{t})$ as a key regulator for their development and function. These ILCs can be activated by IL-23 or IL-1 $\beta$ stimulation to produce IL-17 or IL-22 mirroring Th17 and Th22 cells (82).

LTi cells appearing during embryonic development were initially regarded as strictly required for prenatal lymph node development and Peyer's patches (PPs), and also thought to be important in the development of the adaptive immune system $(82,83)$. However, CCR6-expressing LTi-ILC3s (CCR6 ${ }^{+}$ ILC3s), which share several characteristics with embryonic LTi cells, such as co-expression of CD4 and the production of IL-17 (Fig. 2) (84), can be found in mLNs and the colon lamina propria (cLPL) of healthy adult mice (85).

CCR6- ILC3s, which produce only IL-22 and account for a small proportion of ILC3s perinatally, increased significantly within 4 weeks after birth $(84,86)$, and $\mathrm{PLZF}^{+}$common helper-like ILC progenitor (CHILP) cells seem likely to be a specific CCR6- ILC3 progenitor, which make CCR6- ILC3s differ from other ILC3s (84). Moreover, some studies have demonstrated that CCR6- ILC3s use distinct transcriptional regulation pathways for their development $(84,87)$, and there are some differences within CCR6- ILC3s in terms of their activation since CCR6-NKp46- ILC3s do not require T-bet for cell differentiation and maintenance, but CCR6-NKp46 ${ }^{+}$ ILC3s do require T-bet (48).

Although the proportion of ILC3s accounts for less than $5 \%$ of lamina propria lymphocytes, it has been shown that this cell type is one of the major sources of IL-22, which plays a crucial role in mucosal immune defense. CCR6 ${ }^{+}$ILC3s regulate immunity against infection and disease through the secretion of IL-17 and IL-22, in addition to their key role in organogenesis $(82,88)$. For example, one study found that intestinal tissue homeostasis could be supported by $\mathrm{CCR}^{+}$ILC3-derived IL-22 in a graft-vs.-host disease model (89). Another study showed that this CCR6 ${ }^{+}$ILC3-derived IL-22 also promotes the induction of intestinal fucosylation of the intestinal epithelium with the cooperation of lymphotoxin, which is also derived from CCR6 ${ }^{+}$ILC3s (90). CCR6-NKp46 ${ }^{+}$ILC3s in the small intestine also contribute to mucosal immunity against Citrobacter rodentium $(C$. rodentium) through production of IL-22 in $\mathrm{Rag}^{-/-} \mathrm{Il} 2 \mathrm{rg}^{-/}$mice (80). In addition, ILC3s have been thought to play a role in the intestinal defenses in Salmonella typhimurium (91), Candida albicans (92) and Streptococcus pneumoniae (93) models. It has also been proposed that IL-22-producing CCR6-NKp46+ ILC3s have an impact on the resistance to bacterial invasion in the colitis model $(94,95)$, and modulate eosinophil infiltration and lymphocyte invasion in allergic airway hyperreactivity (AHR) in the lung (96). These all suggest a role of ILC3s in homeostasis in multiple tissues following inflammation or damage.

\section{Relationship between ILCs and obesity}

Although it is accepted that genetic and environmental factors were originally thought to be the major influences on the development of obesity, many researches have now shown that immunological factors can also contribute to the pathogenesis of obesity. Nowadays, several types of immune cells have been recognized as critical regulators of metabolic homeostasis $(97,98)$, and this crosstalk likely involves immune cells and low-grade inflammation, particularly in many organs besides the adipose tissue, including the pancreas, liver and intestines, which all showed as an emerging characteristics and made a potentially regulatory force behind the development of obesity $(97,99)$.

ILCs are now recognized as a new regulator involved in adipose tissue and in metabolic homeostasis $(10,100)$. Most studies of ILCs and their role in metabolism have focused on ILC $2 \mathrm{~s}$, which have been reported to play a role in maintaining metabolic homeostasis, since ILC2s and eosinophils are predominantly resident in lean adipose tissue, and are considered as 'upstream' regulators of M2 macrophages in adipose tissue (77). Various studies have shown that, with the cooperation of eosinophils and M2 macrophages, ILC2s regulate obesity, beige conversion of white adipose tissue and beige fat biogenesis (Fig. 3) $(76,77,101)$. The production of IL-5 and IL-13 from ILC2s in VAT has been shown to be essential for eosinophil and M2 macrophage differentiation and activation, both of which act as important regulators of obesity (77). In addition, ILC2 deficiency in $\operatorname{Rag}^{-/-}$mice resulted in significantly reduced numbers of eosinophils and M2 macrophages, suggesting that ILC2s alone can promote the development of eosinophils and M2 macrophages in adipose tissue leading to obesity regulation (77,78). IL-33 is another important inducer of ILC2s and can influence the development of obesity. Recent studies have shown the effect of ILC2s on the biogenesis of VAT under IL-33 stimulation, which might regulate obesity (Fig. 3) (76,102). In addition, the numbers of ILC2s were decreased in obese murine epididyma, and this scenario is also found in human abdominal subcutaneous white adipose tissue (76). Notably, IL-33 knock-out mice were shown to have weight gain and reduced frequency and absolute numbers of ILC2s, even when the mice were fed a normal diet (76). However, this situation could be reversed by administration of IL-33, which led to increased numbers of ILC2s, consequently promoting the recovery of M2 macrophage numbers (76).

Roles of cNK cells and ILC1s in obesity have also been demonstrated. One study found that large quantities of IFN- $\gamma$, which may trigger M1 macrophages in VAT, may be derived from cNK cells in HFD-induced obesity (103). Moreover, systemic depletion of $\mathrm{NK} 1.1^{+}$or $\mathrm{NKp}_{4} 6^{+}$cells decreased diet-induced insulin resistance by restricting the polarization of M1 macrophages, but did not decrease obesity, suggesting that cNK cells affect inflammation-related insulin resistance rather than metabolism directly $(103,104)$. In addition, 


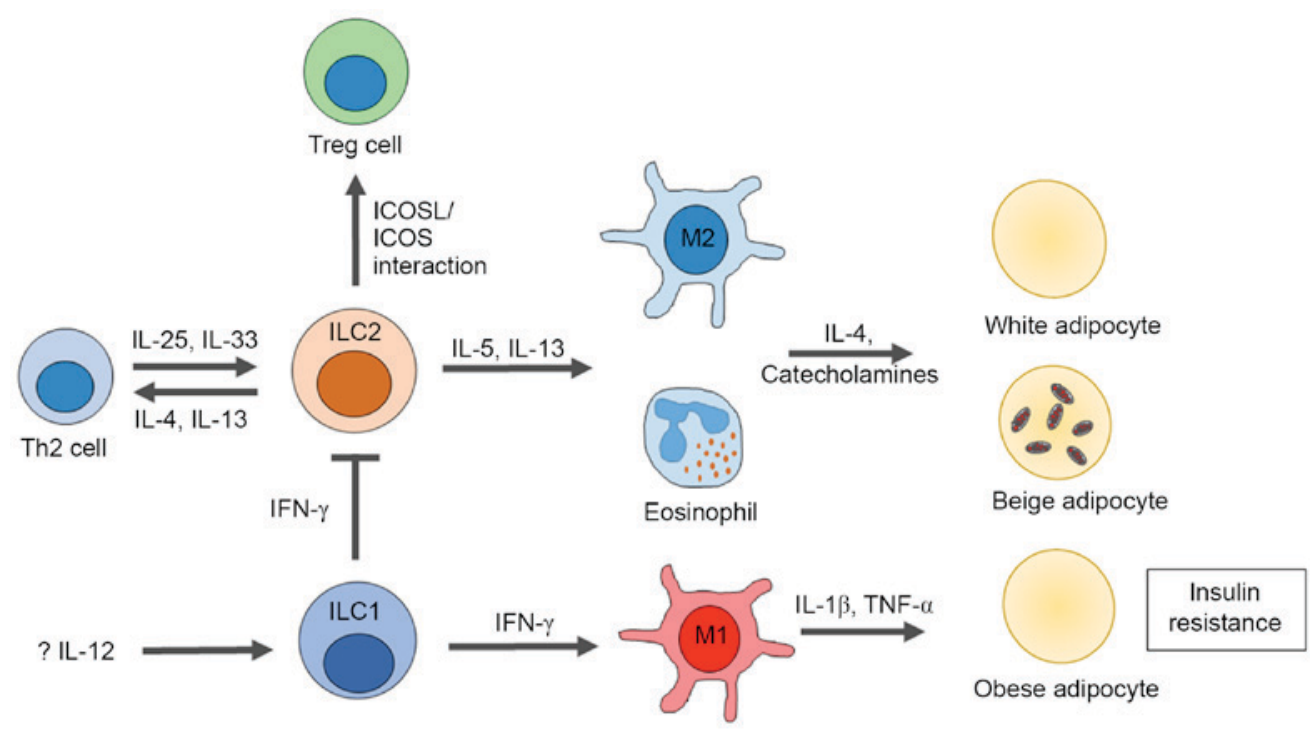

Figure 3. Influences of ILCs on obesity and insulin resistance. In the healthy state, adipose tissue inflammation is suppressed by IL-5 and IL-13, secreted by ILC2s that contribute to the activation of M2 macrophages and eosinophils. Moreover, the productions of IL- 4 and IL-13 from ILC2s also promote Th2 development. The inflammatory condition of adipose tissue in obesity is associated with increased infiltration of M1 macrophages, neutrophils, Th1 and CD8 ${ }^{+} \mathrm{T}$ cells. Recently, the role of ILC1 s in adipose tissue inflammation has been identified, which are mediated by the secretion of IFN- $\gamma$ that promote M1 macrophage polarization and ILC2 suppression. ILC, innate lymphoid cell; ILC1, group 1 ILC; ILC2, group 2 ILC; Treg, regulatory T cells; TNF- $\alpha$, tumor necrosis factor- $\alpha$.

adoptive transfer of splenic NK cells into the VAT of IFN- $\gamma$ knock-out mice could restore insulin resistance following HFD induction (103), implying that this cell type may be a major regulator promoting insulin resistance. Tissue resident group 1 ILCs have also been recently reported to contribute to obesity-associated insulin resistance in the absence of the influence of $\mathrm{T}$ and/or NKT cells (105). The same study also reported that IL-12, which were undefined for upstream signals and cellular sources, could activate adipose ILC1s, leading to the production of IFN- $\gamma$, and the polarization of M1 macrophages in adipose tissue at the early stage of HFD consumption (Fig. 3) (105). Mirroring the Th1-Th2 balance, IFN- $\gamma$, which is partly derived from ILC1s, can counteract the IL-33 function and interfere with the activation of ILC2s in infected tissues, as well as in healthy adipose tissues (72). Therefore, ILC1s may indirectly affect ILC2-mediated regulation of obesity (Fig. 3).

Although there are currently no specific experiments describing either the effects of ILC3s in adipose tissues or its role or roles in HFD-induced obesity, it has been hypothesized that IL-17 and/or IL-22 secreted from ILC3s might affect obesity or metabolic homeostasis (10). ILC3-derived IL-17 has been shown to be associated with obesity-related diseases such as AHR (106). This same study also demonstrated that AHR

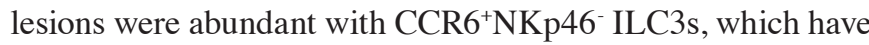
the ability to secrete excessive IL-17 (106). Moreover, the same study found that $\mathrm{Ragl}^{-/} \mathrm{IL}-17 \mathrm{~A}^{-/-}$mice did not develop AHR under HFD conditions, but transferring CCR6 ${ }^{+} \mathrm{NKp} 46^{-}$ILC3s into the $\mathrm{Rag}^{-1} I L-2 R \gamma^{-1-}$ mice resulted in AHR under HFD feeding, suggesting a role of IL-17 and ILC3s on AHR pathogenesis (106). However, it has also been reported that IL-22, for which ILC3s were the major source, has been found to alleviate metabolic abnormalities, including insulin resistance and hyperglycemia via changes in liver metabolism (107). This same study showed that $I L-22 R^{-/-}$mice were highly susceptible to HFD-induced obesity and insulin resistance, but these events improved when IL-22 was administrated to the obese mice. Another study also demonstrated a protective role of IL-22 against diabetes, partly through modulating oxidative stress and inflammation pathways related to islet $\beta$ cells, promoting the secretion of insulin and fully restored glucose insulin sensitivity in obese mice (108).

\section{Determining whether intestinal ILCs influence the development of obesity}

As mentioned previously, energy balance and gut homeostasis of the host may be influenced by diet and gut microbiota composition, and, in metabolically abnormal conditions, increased intestinal permeability and inflammation may play a role in the adipose tissue inflammatory response $(9,24)$. The gut is resided by extensive immune system, and recent studies have investigated changes in intestinal inflammatory and immune cell populations with regard to their roles in obesity and insulin resistance $(109,110)$.

Early reports have shown increasing levels of gut inflammatory cytokines, such as TNF- $\alpha$, IL- $1 \beta$ and IL-12, which are mostly produced by innate immune cells during HFD feeding, and these increases are related to weight gain, adiposity, plasma insulin and glucose levels $(99,111)$. Interestingly, these expressions were detected in bowel immune cells, especially in PPs and lymphoid aggregates, in which ILCs are resident (112). However, this intestinal inflammatory response was not found in HFD-fed germ-free mice, suggesting the microbiota are a driving force behind intestinal inflammation (111). Recent evidence has also demonstrated high expression levels of several pro-inflammatory cytokines, including IFN- $\gamma$ and IL-1 $\beta$, in the duodenum of insulin-resistant obese patients (113), and IL-23, TNF- $\alpha$, TGF- $\beta$, CCL5, and IFN- $\gamma$ in the combined lamina propria and epithelial fraction of obese subjects (114). Specifically, there are many studies which have investigated changes of particular types of intestinal immune cells in 
obese subjects. One study found that the intestinal frequency of $\gamma \delta \mathrm{T}$ cells was changed in mice with HFD feeding (109). This type of innate immune cell is predominantly found in the intraepithelial lymphocyte fraction, and the same study found that the numbers of IL-17-producing $\gamma \delta \mathrm{T}$ cells in the small intestine increased after 3 weeks of HFD consumption, and after 12 weeks in both the colon and small bowel (109). Another study found that intestinal eosinophils were also decreased in both number and proportion after 1 week of HFD feeding (115). This reduction was correlated with intestinal permeability of HFD mice predominantly in the ileum. Another study also demonstrated that total macrophage density and the numbers of mature DCs and NK cells were increased in obese diabetic and obese non-diabetic humans (114).

HFD has been shown not only to be active in innate immune cells, but it can also alter the proportions of adaptive immune cells in the intestinal community. One study found that the percentages of Treg cells, which play an important role in inflammatory suppression, were decreased after 3 weeks of HFD consumption, while the quantity of $\mathrm{CD}^{+}$ and $\mathrm{CD}^{+}$cells did not show any significant differences in this period, but were higher after 12 weeks of HFD feeding (109). Obese human subjects also showed increased T-bet expression and $\mathrm{CD}^{+} \mathrm{T}$ cells and reduced Foxp3 (Treg) cells in both the small bowel and colon compared to lean subjects $(109,114)$. Reduced numbers and frequency of Th17 cells were also found in HFD-fed mice, apparently related to alterations of the commensal bacteria populations, such as segmented filamentous bacteria (SFB) and Porphyromonas gingivalis (110). Another study found that decreased numbers of Th17 and SFB were correlated with an abnormal gut barrier and increased adiposity, linking the role of microbiota and adaptive immunity to obesity (116).

Although the roles of ILCs on metabolic homeostasis have been intensively studied, to date such studies have focused only on adipose tissue ILCs, and these findings may not represent the overall contributions of this cell type on obesity, since other organs such as the intestine also displayed low-grade chronic inflammatory changes in obese persons. There are few studies to date which have examined the role of gut ILCs on intestinal inflammation and homeostasis after HFD-feeding, and until now only ILC3s, which are very abundant within the intestine, have been reported to be associated with mucosal homeostasis during obesity (107). This information is consistent with the reduction of $\mathrm{CCR}^{+} \mathrm{NKp} 46^{+}$ILC3s in the lamina propria of HFD-fed mice, and this seems to be related to lower mucosal barrier integrity and increased serum LPS (109). However, no current reports have demonstrated a role for HFD in all types of intestinal ILCs, which directly contact with diets and gut microbiota, and may contribute to colon homeostasis in obesity.

\section{Conclusion}

Like macrophages, ILCs were first described as a player in the innate immune system against several types of pathogens, but new studies on these immune cells have proposed that ILCs may also be a player in metabolic homeostasis. ILC2s appear to be regulators of anti-inflammatory conditions in the lean state while ILC1s seem to be involved in promoting the development of obesity and other metabolic diseases by secreting inflammatory factors in the obese state. Although these roles and the characterizations of ILCs have been well documented in many studies, most investigations to date have focused on the function of this cell in adipose tissue, but since the primary functions of this type of cell are carried out in barrier tissues such as the liver, intestine and other abdominal viscera, which all affect the progression of obesity and metabolic diseases, new research should examine the influence of these cells in other organs on the development of obesity and metabolic abnormalities.

\section{References}

1. Boulangé CL, Neves AL, Chilloux J, Nicholson JK and Dumas ME: Impact of the gut microbiota on inflammation, obesity and metabolic disease. Genome Med 8: 42, 2016.

2. Lu Y and Loos RJ: Obesity genomics: Assessing the transferability of susceptibility loci across diverse populations. Genome Med 5: 55, 2013.

3. Westerterp KR and Plasqui G: Physically active lifestyle does not decrease the risk of fattening. PLoS One 4: e4745, 2009.

4. DiNicolantonio JJ, O'Keefe JH and Lucan SC: Added fructose: A principal driver of type 2 diabetes mellitus and its consequences. Mayo Clin Proc 90: 372-381, 2015.

5. DiNicolantonio JJ, Lucan SC and O'Keefe JH: The evidence for saturated fat and for sugar related to coronary heart disease. Prog Cardiovasc Dis 58: 464-472, 2016.

6. Gregor MF and Hotamisligil GS: Inflammatory mechanisms in obesity. Annu Rev Immunol 29: 415-445, 2011.

7. Sell H, Habich C and Eckel J: Adaptive immunity in obesity and insulin resistance. Nat Rev Endocrinol 8: 709-716, 2012.

8. Purkayastha S and Cai D: Neuroinflammatory basis of metabolic syndrome. Mol Metab 2: 356-363, 2013

9. Cani PD, Amar J, Iglesias MA, Poggi M, Knauf C, Bastelica D, Neyrinck AM, Fava F, Tuohy KM, Chabo C, et al: Metabolic endotoxemia initiates obesity and insulin resistance. Diabetes 56: 1761-1772, 2007.

10. Yang D, Yang W, Tian Z, van Velkinburgh JC, Song J, Wu Y and Ni B: Innate lymphoid cells as novel regulators of obesity and its-associated metabolic dysfunction. Obes Rev 17: 485-498, 2016.

11. Hotamisligil GS: Inflammation and metabolic disorders. Nature 444: 860-867, 2006.

12. Shi H, Kokoeva MV, Inouye K, Tzameli I, Yin H and Flier JS: TLR4 links innate immunity and fatty acid-induced insulin resistance. J Clin Invest 116: 3015-3025, 2006.

13. Ley RE, Bäckhed F, Turnbaugh P, Lozupone CA, Knight RD and Gordon JI: Obesity alters gut microbial ecology. Proc Natl Acad Sci USA 102: 11070-11075, 2005.

14. Venkatesh M, Mukherjee S, Wang H, Li H, Sun K, Benechet AP, Qiu Z, Maher L, Redinbo MR, Phillips RS, et al: Symbiotic bacterial metabolites regulate gastrointestinal barrier function via the xenobiotic sensor PXR and Toll-like receptor 4. Immunity 41: 296-310, 2014

15. Zhang C, Zhang M, Wang S, Han R, Cao Y, Hua W, Mao Y, Zhang $\mathrm{X}$, Pang $\mathrm{X}$, Wei C, et al: Interactions between gut microbiota, host genetics and diet relevant to development of metabolic syndromes in mice. ISME J 4: 232-241, 2010.

16. Sekirov I, Russell SL, Antunes LC and Finlay BB: Gut microbiota in health and disease. Physiol Rev 90: 859-904, 2010.

17. Turnbaugh PJ,Hamady M, Yatsunenko T, Cantarel BL, Duncan A, Ley RE, Sogin ML, Jones WJ, Roe BA, Affourtit JP, et al: A core gut microbiome in obese and lean twins. Nature 457: 480-484, 2009.

18. Trompette A, Gollwitzer ES, Yadava K, Sichelstiel AK, Sprenger N, Ngom-Bru C, Blanchard C, Junt T, Nicod LP, Harris NL and Marsland BJ: Gut microbiota metabolism of dietary fiber influences allergic airway disease and hematopoiesis. Nat Med 20: $159-166,2014$.

19. Ley RE, Turnbaugh PJ, Klein S and Gordon JI: Microbial ecology: Human gut microbes associated with obesity. Nature 444: 1022-1023, 2006.

20. Schwiertz A, Taras D, Schäfer K, Beijer S, Bos NA, Donus C and Hardt PD: Microbiota and SCFA in lean and overweight healthy subjects. Obesity (Silver Spring) 18: 190-195, 2010. 
21. Duncan SH, Lobley GE, Holtrop G, Ince J, Johnstone AM, Louis P and Flint HJ: Human colonic microbiota associated with diet, obesity and weight loss. Int J Obes (Lond) 32: 1720-1724, 2008.

22. Montiel-Castro AJ, González-Cervantes RM, Bravo-Ruiseco G and Pacheco-López G: The microbiota-gut-brain axis: Neurobehavioral correlates, health and sociality. Front Integr Neurosci 7: 70, 2013.

23. Harris K, Kassis A, Major G and Chou CJ: Is the gut microbiota a new factor contributing to obesity and its metabolic disorders? J Obes 2012: 879151, 2012.

24. Amar J, Chabo C, Waget A, Klopp P, Vachoux C, BermúdezHumarán LG, Smirnova N, Bergé M, Sulpice T, Lahtinen S, et al: Intestinal mucosal adherence and translocation of commensal bacteria at the early onset of type 2 diabetes: Molecular mechanisms and probiotic treatment. EMBO Mol Med 3: 559-572, 2011

25. Cox LM and Blaser MJ: Pathways in microbe-induced obesity. Cell Metab 17: 883-894, 2013

26. Burcelin R, Garidou L and Pomié C: Immuno-microbiota cross and talk: The new paradigm of metabolic diseases. Semin Immunol 24 $67-74,2012$

27. Mosser DM and Edwards JP: Exploring the full spectrum of macrophage activation. Nat Rev Immunol 8: 958-969, 2008.

28. Red Eagle A and Chawla A: In obesity and weight loss, all roads lead to the mighty macrophage. J Clin Invest 120: 3437-3440, 2010.

29. Kratz M, Coats BR, Hisert KB, Hagman D, Mutskov V, Peris E, Schoenfelt KQ, Kuzma JN, Larson I, Billing PS, et al: Metabolic dysfunction drives a mechanistically distinct proinflammatory phenotype in adipose tissue macrophages. Cell Metab 20: 614-625, 2014.

30. Xu X, Grijalva A, Skowronski A, van Eijk M, Serlie MJ and Ferrante AW Jr: Obesity activates a program of lysosomal-dependent lipid metabolism in adipose tissue macrophages independently of classic activation. Cell Metab 18: 816-830, 2013.

31. Feuerer M, Herrero L, Cipolletta D, Naaz A, Wong J, Nayer A, Lee J, Goldfine AB, Benoist C, Shoelson S and Mathis D: Lean, but not obese, fat is enriched for a unique population of regulatory $\mathrm{T}$ cells that affect metabolic parameters. Nat Med 15: 930-939, 2009.

32. Strissel KJ, DeFuria J, Shaul ME, Bennett G, Greenberg AS and Obin MS: T-cell recruitment and Th1 polarization in adipose tissue during diet-induced obesity in C57BL/6 mice. Obesity (Silver Spring) 18: 1918-1925, 2010.

33. Spits H, Artis D, Colonna M, Diefenbach A, Di Santo JP, Eberl G, Koyasu S, Locksley RM, McKenzie AN, Mebius RE, et al: Innate lymphoid cells - a proposal for uniform nomenclature. Nat Rev Immunol 13: 145-149, 2013.

34. Spits $\mathrm{H}$ and Cupedo T: Innate lymphoid cells: Emerging insights in development, lineage relationships and function. Annu Rev Immunol 30: 647-675, 2012.

35. Artis D and Spits H: The biology of innate lymphoid cells Nature 517: 293-301, 2015.

36. Villanova F, Flutter B, Tosi I, Grys K, Sreeneebus H, Perera GK, Chapman A, Smith CH, Di Meglio P and Nestle FO: Characterization of innate lymphoid cells in human skin and blood demonstrates increase of $\mathrm{NKp} 44^{+}$ILC3 in psoriasis. J Invest Dermatol 134: 984-991, 2014.

37. Fuchs A and Colonna M: Innate lymphoid cells in homeostasis, infection, chronic inflammation and tumors of the gastrointestinal tract. Curr Opin Gastroenterol 29: 581-587, 2013.

38. Cortez VS, Robinette ML and Colonna M: Innate lymphoid cells: New insights into function and development. Curr Opin Immunol 32: 71-77, 2015.

39. Cortez VS and Colonna M: Diversity and function of group 1 innate lymphoid cells. Immunol Lett 179: 19-24, 2016.

40. Sun JC and Lanier LL: NK cell development, homeostasis and function: Parallels with $\mathrm{CD}^{+} \mathrm{T}$ cells. Nat Rev Immunol 11: 645-657, 2011.

41. Robinette ML, Fuchs A, Cortez VS, Lee JS, Wang Y, Durum SK, Gilfillan S and Colonna M; Immunological Genome Consortium: Transcriptional programs define molecular characteristics of innate lymphoid cell classes and subsets. Nat Immunol 16 306-317, 2015

42. Fuchs A, Vermi W, Lee JS, Lonardi S, Gilfillan S, Newberry RD, Cella $\mathrm{M}$ and Colonna $\mathrm{M}$ : Intraepithelial type 1 innate lymphoid cells are a unique subset of IL-12- and IL-15-responsive IFN- $\gamma$-producing cells. Immunity 38: 769-781, 2013.

43. Vivier E, Raulet DH, Moretta A, Caligiuri MA, Zitvogel L, Lanier LL, Yokoyama WM and Ugolini S: Innate or adaptive immunity? The example of natural killer cells. Science 331: 44-49, 2011.
44. Cichicki F, Schlums H, Theorell J, Tesi B, Miller JS, Ljunggren HG and Bryceson YT: Diversification and functional specialization of human NK cell subsets. Curr Top Microbiol Immunol 395: 63-94, 2016.

45. Fuchs A: ILC1s in tissue inflammation and infection. Front Immunol 7: 104, 2016

46. Gasteiger G, Fan X, Dikiy S, Lee SY and Rudensky AY: Tissue residency of innate lymphoid cells in lymphoid and nonlymphoid organs. Science 350: 981-985, 2015.

47. Peng H, Jiang X, Chen Y, Sojka DK, Wei H, Gao X, Sun R, Yokoyama WM and Tian Z: Liver-resident NK cells confer adaptive immunity in skin-contact inflammation. J Clin Invest 123 1444-1456, 2013.

48. Klose CSN, Flach M, Möhle L, Rogell L, Hoyler T, Ebert K, Fabiunke C, Pfeifer D, Sexl V, Fonseca-Pereira D, et al: Differentiation of type 1 ILCs from a common progenitor to all helper-like innate lymphoid cell lineages. Cell 157: 340-356, 2014.

49. Daussy C, Faure F, Mayol K, Viel S, Gasteiger G, Charrier E, Bienvenu J, Henry T, Debien E, Hasan UA, et al: T-bet and Eomes instruct the development of two distinct natural killer cell lineages in the liver and in the bone marrow. J Exp Med 211: 563-577, 2014

50. Spits H, Bernink JH and Lanier L: NK cells and type 1 innate lymphoid cells: Partners in host defense. Nat Immunol 17: 758-764, 2016.

51. Sonnenberg GF and Artis D: Innate lymphoid cells in the initiation, regulation and resolution of inflammation. Nat Med 21: 698-708, 2015.

52. Vivier E, Tomasello E, Baratin M, Walzer T and Ugolini S: Functions of natural killer cells. Nat Immunol 9: 503-510, 2008.

53. Karta MR, Broide DH and Doherty TA: Insights into group 2 innate lymphoid cells in human airway disease. Curr Allergy Asthma Rep 16: 8, 2016

54. Walker JA, Barlow JL and McKenzie AN: Innate lymphoid cells - how did we miss them? Nat Rev Immunol 13: 75-87, 2013.

55. Hoyler T, Klose CS, Souabni A, Turqueti-Neves A, Pfeifer D, Rawlins EL, Voehringer D, Busslinger M and Diefenbach A: The transcription factor GATA-3 controls cell fate and maintenance of type 2 innate lymphoid cells. Immunity 37: 634-648, 2012

56. Wong SH, Walker JA, Jolin HE, Drynan LF, Hams E, Camelo A, Barlow JL, Neill DR, Panova V, Koch U, et al: Transcription factor ROR $\alpha$ is critical for nuocyte development. Nat Immunol 13: 229-236, 2012

57. Moro K, Yamada T, Tanabe M, Takeuchi T, Ikawa T, Kawamoto H, Furusawa J, Ohtani M, Fujii $\mathrm{H}$ and Koyasu S: Innate production of $\mathrm{T}(\mathrm{H}) 2$ cytokines by adipose tissue-associated c-Kit(+)Sca-1(+) lymphoid cells. Nature 463: 540-544, 2010

58. Saenz SA, Siracusa MC, Perrigoue JG, Spencer SP, Urban JF Jr, Tocker JE, Budelsky AL, Kleinschek MA, Kastelein RA, Kambayashi T, et al: IL25 elicits a multipotent progenitor cell population that promotes $\mathrm{T}(\mathrm{H}) 2$ cytokine responses. Nature 464 : 1362-1366, 2010

59. Gentek R, Munneke JM, Helbig C, Blom B, Hazenberg MD, Spits H and Amsen D: Modulation of signal strength switches notch from an inducer of T cells to an inducer of ILC2. Front Immunol 4: 334, 2013

60. Price AE,Liang HE, Sullivan BM, Reinhardt RL, Eisley CJ, Erle DJ and Locksley RM: Systemically dispersed innate IL-13-expressing cells in type 2 immunity. Proc Natl Acad Sci USA 107: 11489-11494, 2010.

61. Tait Wojno ED and Artis D: Innate lymphoid cells: Balancing immunity, inflammation and tissue repair in the intestine. Cell Host Microbe 12: 445-457, 2012

62. Neill DR, Wong SH, Bellosi A, Flynn RJ, Daly M, Langford TK, Bucks C, Kane CM, Fallon PG, Pannell R, et al: Nuocytes represent a new innate effector leukocyte that mediates type-2 immunity. Nature 464: 1367-1370, 2010.

63. Wilhelm C, Turner JE, Van Snick J and Stockinger B: The many lives of IL-9: A question of survival? Nat Immunol 13: 637-641, 2012.

64. Doherty TA and Broide DH: Group 2 innate lymphoid cells: New players in human allergic diseases. J Investig Allergol Clin Immunol 25: 1-11; quiz 2p following 11, 2015.

65. Oliphant CJ, Hwang YY, Walker JA, Salimi M, Wong SH, Brewer JM, Englezakis A, Barlow JL, Hams E, Scanlon ST, et al: MHCII-mediated dialog between group 2 innate lymphoid cells and CD4(+) T cells potentiates type 2 immunity and promotes parasitic helminth expulsion. Immunity 41: 283-295, 2014.

66. Drake LY, Iijima K and Kita H: Group 2 innate lymphoid cells and $\mathrm{CD} 4^{+} \mathrm{T}$ cells cooperate to mediate type 2 immune response in mice. Allergy 69: 1300-1307, 2014. 
67. Fajt ML, Gelhaus SL, Freeman B, Uvalle CE, Trudeau JB, Holguin $F$ and Wenzel SE: Prostaglandin $\mathrm{D}_{2}$ pathway upregulation: Relation to asthma severity, control and TH2 inflammation. J Allergy Clin Immunol 131: 1504-1512, 2013.

68. Yu X, Pappu R, Ramirez-Carrozzi V, Ota N, Caplazi P, Zhang J, Yan D, Xu M, Lee WP and Grogan JL: TNF superfamily member TL1A elicits type 2 innate lymphoid cells at mucosal barriers. Mucosal Immunol 7: 730-740, 2014

69. Motomura Y, Morita H, Moro K, Nakae S, Artis D, Endo TA, Kuroki Y, Ohara O, Koyasu S and Kubo M: Basophil-derived interleukin-4 controls the function of natural helper cells, a member of ILC2s, in lung inflammation. Immunity 40: 758-771, 2014.

70. Maazi H, Patel N, Sankaranarayanan I, Suzuki Y, Rigas D, Soroosh P, Freeman GJ, Sharpe AH and Akbari O: ICOS ICOS-ligand interaction is required for type 2 innate lymphoid cell function, homeostasis and induction of airway hyperreactivity. Immunity 42: 538-551, 2015.

71. Salimi M, Barlow JL, Saunders SP, Xue L, Gutowska-Owsiak D, Wang X, Huang LC, Johnson D, Scanlon ST, McKenzie AN, et al: A role for IL-25 and IL-33-driven type-2 innate lymphoid cells in atopic dermatitis. J Exp Med 210: 2939-2950, 2013.

72. Molofsky AB, Van Gool F, Liang HE, Van Dyken SJ, Nussbaum JC, Lee J, Bluestone JA and Locksley RM: Interleukin-33 and interferon- $\gamma$ counter-regulate group 2 innate lymphoid cell activation during immune perturbation. Immunity 43: 161-174, 2015.

73. Walford HH and Doherty TA: Diagnosis and management of eosinophilic asthma: A US perspective. J Asthma Allergy 7: 53-65, 2014

74. Oboki K, Ohno T, Kajiwara N, Arae K, Morita H, Ishii A, Nambu A, Abe T, Kiyonari H, Matsumoto K, et al: IL-33 is a crucial amplifier of innate rather than acquired immunity. Proc Natl Acad Sci USA 107: 18581-18586, 2010.

75. Chang YJ, Kim HY, Albacker LA, Baumgarth N, McKenzie AN Smith DE, Dekruyff RH and Umetsu DT: Innate lymphoid cells mediate influenza-induced airway hyper-reactivity independently of adaptive immunity. Nat Immunol 12: 631-638, 2011.

76. Brestoff JR, Kim BS, Saenz SA, Stine RR, Monticelli LA, Sonnenberg GF, Thome JJ, Farber DL, Lutfy K, Seale P and Artis D: Group 2 innate lymphoid cells promote beiging of white adipose tissue and limit obesity. Nature 519: 242-246, 2015.

77. Molofsky AB, Nussbaum JC, Liang HE, Van Dyken SJ, Cheng LE, Mohapatra A, Chawla A and Locksley RM: Innate lymphoid type 2 cells sustain visceral adipose tissue eosinophils and alternatively activated macrophages. J Exp Med 210: 535-549, 2013

78. Hams E, Locksley RM, McKenzie AN and Fallon PG: Cutting edge: IL-25 elicits innate lymphoid type 2 and type II NKT cells that regulate obesity in mice. J Immunol 191: 5349-5353, 2013.

79. Spencer SP, Wilhelm C, Yang Q, Hall JA, Bouladoux N, Boyd A Nutman TB, Urban JF Jr, Wang J, Ramalingam TR, et al: Adaptation of innate lymphoid cells to a micronutrient deficiency promotes type 2 barrier immunity. Science 343: 432-437, 2014.

80. Satoh-Takayama N, Vosshenrich CA, Lesjean-Pottier S, Sawa S, Lochner M, Rattis F, Mention JJ, Thiam K, Cerf-Bensussan N, Mandelboim O, et al: Microbial flora drives interleukin 22 production in intestinal $\mathrm{NKp} 46^{+}$cells that provide innate mucosal immune defense. Immunity 29: 958-970, 2008.

81. Cella M, Fuchs A, Vermi W, Facchetti F, Otero K, Lennerz JK, Doherty JM, Mills JC and Colonna M: A human natural killer cell subset provides an innate source of IL-22 for mucosal immunity. Nature 457: 722-725, 2009.

82. Satoh-Takayama N: Heterogeneity and diversity of group 3 innate lymphoid cells: New cells on the block. Int Immunol 28: 29-34, 2016.

83. van de Pavert SA and Vivier E: Differentiation and function of group 3 innate lymphoid cells, from embryo to adult. Int Immunol 28: 35-42, 2016

84. Klose CS, Kiss EA, Schwierzeck V, Ebert K, Hoyler T, d'Hargues Y, Göppert N, Croxford AL, Waisman A, Tanriver Y and Diefenbach A: A T-bet gradient controls the fate and function of CCR6-ROR $\gamma \mathrm{t}^{+}$innate lymphoid cells. Nature 494: 261-265, 2013.

85. Hepworth MR, Fung TC, Masur SH, Kelsen JR, McConnell FM, Dubrot J, Withers DR, Hugues S, Farrar MA, Reith W, et al: Immune tolerance. Group 3 innate lymphoid cells mediate intestinal selection of commensal bacteria-specific $\mathrm{CD} 4^{+} \mathrm{T}$ cells Science 348: 1031-1035, 2015.
86. Sawa S, Cherrier M, Lochner M, Satoh-Takayama N, Fehling HJ, Langa F, Di Santo JP and Eberl G: Lineage relationship analysis of ROR $\gamma \mathrm{t}^{+}$innate lymphoid cells. Science 330: 665-669, 2010.

87. Rankin LC, Groom JR, Chopin M, Herold MJ, Walker JA, Mielke LA, McKenzie AN, Carotta S, Nutt SL and Belz GT: The transcription factor T-bet is essential for the development of NKp $46^{+}$innate lymphocytes via the Notch pathway. Nat Immunol 14: 389-395, 2013.

88. Takatori H, Kanno Y, Watford WT, Tato CM, Weiss G, Ivanov II, Littman DR and O'Shea JJ: Lymphoid tissue inducer-like cells are an innate source of IL-17 and IL-22. J Exp Med 206: 35-41, 2009.

89. Hanash AM, Dudakov JA, Hua G, O'Connor MH, Young LF, Singer NV, West ML, Jenq RR, Holland AM, Kappel LW, et al: Interleukin-22 protects intestinal stem cells from immune-mediated tissue damage and regulates sensitivity to graft versus host disease. Immunity 37: 339-350, 2012

90. Pickard JM, Maurice CF, Kinnebrew MA, Abt MC, Schenten D, Golovkina TV, Bogatyrev SR, Ismagilov RF, Pamer EG, Turnbaugh PJ and Chervonsky AV: Rapid fucosylation of intestinal epithelium sustains host-commensal symbiosis in sickness. Nature 514: 638-641, 2014

91. Goto Y, Obata T, Kunisawa J, Sato S, Ivanov II, Lamichhane A, Takeyama N, Kamioka M, Sakamoto M, Matsuki T, et al: Innate lymphoid cells regulate intestinal epithelial cell glycosylation. Science 345: 1254009, 2014.

92. Gladiator A, Wangler N, Trautwein-Weidner K and LeibundGutLandmann S: Cutting edge: IL-17-secreting innate lymphoid cells are essential for host defense against fungal infection. J Immunol 190: 521-525, 2013

93. Van Maele L, Carnoy C, Cayet D, Ivanov S, Porte R, Deruy E, Chabalgoity JA, Renauld JC, Eberl G, Benecke AG, et al: Activation of type 3 innate lymphoid cells and interleukin 22 secretion in the lungs during Streptococcus pneumoniae infection. J Infect Dis 210: 493-503, 2014

94. Kirchberger S, Royston DJ, Boulard O, Thornton E, Franchini F, Szabady RL, Harrison O and Powrie F: Innate lymphoid cells sustain colon cancer through production of interleukin-22 in a mouse model. J Exp Med 210: 917-931, 2013.

95. Sawa S, Lochner M, Satoh-Takayama N, Dulauroy S, Bérard M, Kleinschek M, Cua D, Di Santo JP and Eberl G: ROR $\gamma \mathrm{t}^{+}$ innate lymphoid cells regulate intestinal homeostasis by integrating negative signals from the symbiotic microbiota. Nat Immunol 12: 320-326, 2011

96. Taube C, Tertilt C, Gyülveszi G, Dehzad N, Kreymborg K, Schneeweiss K, Michel E, Reuter S, Renauld JC, Arnold-Schild D, et al: IL-22 is produced by innate lymphoid cells and limits inflammation in allergic airway disease. PLoS One 6: e21799, 2011.

97. Osborn $\mathrm{O}$ and Olefsky JM: The cellular and signaling networks linking the immune system and metabolism in disease. Nat Med 18: 363-374, 2012.

98. Jin C, Henao-Mejia J and Flavell RA: Innate immune receptors: Key regulators of metabolic disease progression. Cell Metab 17: 873-882, 2013

99. Winer DA, Luck H, Tsai S and Winer S: The intestinal immune system in obesity and insulin resistance. Cell Metab 23: 413-426, 2016.

100. Bostick JW and Zhou L: Innate lymphoid cells in intestinal immunity and inflammation. Cell Mol Life Sci 73: 237-252, 2016.

101. Hashiguchi M, Kashiwakura Y, Kojima H, Kobayashi A, Kanno Y and Kobata T: IL-33 activates eosinophils of visceral adipose tissue both directly and via innate lymphoid cells. Eur J Immunol 45: 876-885, 2015.

102. Lee MW, Odegaard JI, Mukundan L, Qiu Y, Molofsky AB, Nussbaum JC, Yun K, Locksley RM and Chawla A: Activated type 2 innate lymphoid cells regulate beige fat biogenesis. Cell 160: 74-87, 2015

103. Wensveen FM, Jelenčić V, Valentić S, Šestan M, Wensveen TT, Theurich S, Glasner A, Mendrila D, Stimac D, Wunderlich FT, et al: NK cells link obesity-induced adipose stress to inflammation and insulin resistance. Nat Immunol 16: 376-385, 2015.

104. Lee BC, Kim MS, Pae M, Yamamoto Y, Eberlé D, Shimada T, Kamei N, Park HS, Sasorith S, Woo JR, et al: Adipose natural killer cells regulate adipose tissue macrophages to promote insulin resistance in obesity. Cell Metab 23: 685-698, 2016.

105. O'Sullivan TE, Rapp M, Fan X, Weizman OE, Bhardwaj P, Adams NM, Walzer T, Dannenberg AJ and Sun JC: Adiposeresident group 1 innate lymphoid cells promote obesity-associated insulin resistance. Immunity 45: 428-441, 2016. 
106. Kim HY, Lee HJ, Chang YJ, Pichavant M, Shore SA, Fitzgerald KA, Iwakura Y, Israel E, Bolger K, Faul J, et al: IL-17 producing innate lymphoid cells and the NLRP3 inflammasome facilitate obesity-associated airway hyperreactivity. Nat Med 20: 54-61, 2014

107. Wang X, Ota N, Manzanillo P, Kates L, Zavala-Solorio J, Eidenschenk C, Zhang J, Lesch J, Lee WP, Ross J, et al: Interleukin-22 alleviates metabolic disorders and restores mucosal immunity in diabetes. Nature 514: 237-241, 2014.

108. Hasnain SZ, Borg DJ, Harcourt BE, Tong H, Sheng YH, Ng CP Das I, Wang R, Chen AC, Loudovaris T, et al: Glycemic control in diabetes is restored by therapeutic manipulation of cytokines that regulate beta cell stress. Nat Med 20: 1417-1426, 2014

109. Luck H, Tsai S, Chung J, Clemente-Casares X, Ghazarian M, Revelo XS, Lei H, Luk CT, Shi SY, Surendra A, et al: Regulation of obesity-related insulin resistance with gut anti-inflammatory agents. Cell Metab 21: 527-542, 2015.

110. Garidou L, Pomié C, Klopp P, Waget A, Charpentier J, Aloulou M, Giry A, Serino M, Stenman L, Lahtinen S, et al: The gut microbiota regulates intestinal CD4 T cells expressing ROR $\gamma \mathrm{t}$ and controls metabolic disease. Cell Metab 22: 100-112, 2015.

111. Ding S, Chi MM, Scull BP, Rigby R, Schwerbrock NM, Magness S, Jobin C and Lund PK: High-fat diet: Bacteria interactions promote intestinal inflammation which precedes and correlates with obesity and insulin resistance in mouse. PLoS One 5: e12191, 2010.
112. Hashiguchi M, Kashiwakura Y, Kojima H, Kobayashi A, Kanno Y and Kobata T: Peyer's patch innate lymphoid cells regulate commensal bacteria expansion. Immunol Lett 165: 1-9, 2015.

113. Veilleux A, Mayeur S, Bérubé JC, Beaulieu JF, Tremblay E, Hould FS, Bossé Y, Richard D and Levy E: Altered intestinal functions and increased local inflammation in insulin-resistant obese subjects: A gene-expression profile analysis. BMC Gastroenterol 15: 119, 2015.

114. Monteiro-Sepulveda M, Touch S, Mendes-Sá C, André S, Poitou C, Allatif O, Cotillard A, Fohrer-Ting H, Hubert EL, Remark R, et al: Jejunal T cell inflammation in human obesity correlates with decreased enterocyte insulin signaling. Cell Metab 22: 113-124, 2015.

115. Johnson AM, Costanzo A, Gareau MG, Armando AM, Quehenberger O, Jameson JM and Olefsky JM: High fat diet causes depletion of intestinal eosinophils associated with intestinal permeability. PLoS One 10: e0122195, 2015.

116. Cox LM, Yamanishi S, Sohn J, Alekseyenko AV, Leung JM, Cho I, Kim SG, Li H, Gao Z, Mahana D, et al: Altering the intestinal microbiota during a critical developmental window has lasting metabolic consequences. Cell 158: 705-721, 2014.

(D) This work is licensed under a Creative Commons Attribution-Non Commercial-NoDerivatives 4.0 International (CC BY-NC-ND 4.0) License. 